\author{
Emmanuel Abeku Essel
}

\title{
CAN CHIEFS BE THE PROBLEM OF GHANA'S DEMOCRATIC POLITICAL SPACE
}

\section{A törzsfönökök lehetnek a ghánai demokratikus politikai ür problémái?}

Emmanuel Abeku Essel, PhD candidate, University of Public Service, Doctoral School of Public Administration, abeabi@yahoo.com or abeabi@314gmail.com

The 1992 Constitution of Ghana gives unfettered privileges to chiefs and their roles with regard to customs and their usages in the country. A whole chapter in the constitution has been dedicated to the chieftaincy institution which clearly indicates their mandates with a caveat that they cannot actively take part in politics. This arrangement, not only makes them feel alienated from the dayto-day-political discourse of the nation, but also leaves them with a sense of loss of their former position. However, since the institution is revered and forms part of the cultural heritage of the country, comments from these chiefs have in most cases shaped the political discussions of the nation positively or negatively. This paper looks at three major statements by some chiefs, the controversies these statements generated and the conclusions drawn. The paper is a desk research and the researcher relied on secondary data.

Keywords:

Constitution, Chiefs, customs, comments

Ghána 1992. évi alkotmánya korlátlan kiváltságokat ad a törzsfönököknek és szerepüknek az országbeli szokásokat és használatukat illetően. Az alkotmány egy egész fejezetét szentelték a törzsfönökség intézményének, amely egyértelmüen jelzi megbizásukat azzal az ellentmondással, hogy a politikai életben nem vehetnek részt aktívan. Ez a rendelkezés nemcsak elidegeniti őket, hogy részt vegyenek a nép mindennapi politikai vitáiban, hanem azt az érzetet kelti bennük, hogy korábbi meghatározó pozíciójukat is elvesztették. Azonban az intézményüket tisztelik, és az ország kulturális örökségének részei, ezért e vezetök észrevételei, megjegyzései legtöbb esetben pozitívan vagy negatívan formálták a politikai vitákat. Ez a cikk néhány fönök három föbb kijelentését elemzi, valamint ezen állitások által generált vitákat és az abból levont következtetéseket vizsgálja. A tanulmány egy másodelemzés, és a kutató másodlagos adatokra támaszkodott.

KulcsszavaK:

Alkotmány, törzsfönökök, szokásos, megjegyzések 


\section{INTRODUCTION}

Ribot asserted that through indirect rule schemes, chiefs had their legitimacy heavily eroded and tainted by the excesses and contradictions that external backing and exigencies of colonial administration produced. ${ }^{1}$ It however appears that the current waves of democratisation in Ghana is giving the chieftaincy institution a new lease of life which is in total contradiction of what pertains in the 1992 Constitution of Ghana. Traditional leaders are gradually asserting their authority. According to Obario, the re-emergence of traditional leaders in the political arena is increasingly being held as 'the panacea for the achievement of decentralised, pluralistic democratic cultures and the strengthening of civil society'.

One unique system of governance among most African nations and Ghana in particular before the introduction of western democracy has been the chieftaincy institution. It is a system, which is headed by traditional rulers or chiefs who are appointed and installed by family heads and kingmakers hailing from a particular family who are heirs to the stool or skin in a given area. It is a system a particular date and time could not be attributed to. However, Adjei traces the existence of the system back to the $13^{\text {th }}$ century arguing that the institution is very much revered by the people who are being governed. ${ }^{3}$ Amoatia Ofori Payin attests to this, and added that it is part of the culture of the people and any attempt to alienate it from the day-to-day life of the people would amount to destroying their culture. ${ }^{4}$

In order to appreciate the relevance of the chieftainship institution, Owusu and Blom, for instance argue that it is extremely vital to understand how it is based on customary village institutions involving general norms and ideas about leadership. ${ }^{5}$ They contend that a ruler's subjects are fully aware of the duties he owes to them and them to him and are able to exert pressure to make him discharge these duties without let or hindrance. Chieftaincy is therefore widely perceived as an embodiment of virtues of political accountability, transparency, service and probity. It is further argued that traditional leaders play a very critical role in the livelihoods of their subjects in the sense that: 1 . they inspire and motivate their people for development in every aspect; 2 . advocate cooperative action; and 3. extol the commitment and total involvement of all members of a community in forming and implementing policies for overall community welfare. They are able to achieve these

J Ribot, African Decentralization: Local Actors, Powers and Accountability (UNRISD Programme on Democracy, Governance and Human Rights, Paper Number 8, Stockholm, 2002).

2 J Obarrio, Legal Pluralism and Peace Process: The Ambiguous Reemergence of Customary Law in Mozambique (Program on Global Security and Cooperation Research Project, Switzerland, 2002).

3 G K Adjei, 'Traditional Akan Royal Chieftaincy Institution: Evolving Ceremonial Protocol in Chieftaincy at Duayaw-Nkwanta in Ghana', Legon Journal of the Humanities 26 (2015), 1-18.

4 O Amoatia Ofori Payin, Chiefs and Traditional Authorities and their Role in the Democratic Order and Governance. Paper Presented at the 9th IEA Ghana Constitutional Review Series, 2010.

5 M Owusu, 'Domesticating Democracy: Culture, Civil Society and Constitutionalism in Africa', Comparative Studies in Society and History 39, no 1 (1997), 120-152; A Blom, 'Ambiguous Political Space: Chiefs, Land and the Poor in Rural Mozambique', in In the Name of the Poor: Contesting Political Space for Poverty Reduction, ed. by Neil Webster and Lars Eng-Perdersen (New York - London: Zed Books, 2002). 
goals because 'their words are much respected, their praise is much appreciated, and their example is emulated' ${ }^{6}$

The institution has undergone struggles in all the political systems that the country has lived under. In the words of Knierzinger:

From 1951-1966, it was up to Kwame Nkrumah to call the tune: contrary to his initial belief in the continuity between African 'communalism' and modern communism, he eventually changed the whole structure of chieftaincy by making sure that virtually all paramount chiefs in Ghana were party stalwarts. ${ }^{7}$

He further alluded to the fact that regimes of:

K.A. Busia and Edward Akufo-Addo as the leading proponents of the chiefly elite again started a sweeping programme of conversion. In spite of the descent of these leaders, the way they instrumentalised chiefly power remained the same. ${ }^{8}$

The long rule of Jerry Rawlings - from 1979 to 2000, with a short break from 1979 to 1981 - was rather ambiguous in its effects on chieftaincy. Despite verbal assaults in the revolutionary beginning, the regime did not re-adopt the policies of Nkrumah. In 1992, after nearly a decade of structural adjustment monitored by the World Bank and Bretton Wood Institutions, the Constitution of the Fourth Republic was drawn up.

As a way of preserving the cultural heritage of the nation since the chiefs are seen as custodians of the traditions and culture of the people, the drafters of the 1992 Constitution devoted a chapter of it to the institution and to ensure its sustainability and protection Act 759 was passed in 2008 to guide the institution. However, Article 276 of the constitution emphatically states that Chiefs shall not take part in active party politics and gives further and better particulars on that:

1. a chief shall not take part in active party politics; and any chief wishing to do so and wish to seek election to Parliament shall abdicate his stool or skin

2. notwithstanding clause (1) of this article and paragraph (c) of clause (3) of article 94 of this Constitution, a chief may be appointed to any public office for which he is otherwise qualified

Article 277 on the other hand gives an exact definition as to who a chief is as:

G Lule, The Role of Traditional Leaders in the 21st Century (Paper presented at the Sheraton Hotel in Kampala on 28 July 1995), 18.

J Knierzinger, 'Chieftaincy and Development in Ghana: From Political Intermediaries to Neotraditional Development Brokers', AP IFEAS 124 (2011), 6.

8 Ibid. 6. 
A person, who, hailing from the appropriate family and lineage, has been validly nominated, elected or selected and enstooled, enskinned or installed as a chief or queen mother in accordance with the relevant customary law and usage.

According to Morton, in pre-colonial times, chieftaincy constituted the axis for the exercise of executive, legislative and judicial powers. ${ }^{9}$ Since the colonial era, the institution has been linked to the politics of Ghana. Various governments, colonial, civilian or military regimes have in one way or the other tried to influence the role of chiefs in political affairs of the nation.

Political space is defined as the possible range of arenas of contestation by a variety of actors at various levels of society usually over mutually valuable resources and interests. Chinsinga stated that, political space offers protagonists the opportunity to contest, challenge and influence the ways in which decisions about their mutual interests and concerns are formulated, executed and even controlled. ${ }^{10}$ The struggle over political space according to Lefebvre, on the other hand entails an interplay between social and power relations shaped by locally situated knowledge and practices in which the contestants often take recourse to planes of discourse, influence, legitimacy and authority in which they have visibly and symbolically significant comparative advantage. ${ }^{11}$ This, therefore, implies that there are multiple political space(s) in which the very same actors might interact but in which they may invoke widely different registers of discourse, influence, legitimacy and authority befitting the context or encounter at a particular point in time.

\section{THE STATEMENT OF THE PROBLEM}

The barring of chiefs in active politics under the current $4^{\text {th }}$ Republican dispensation, if juxtaposed against what they used to enjoy in the past has become a worry to many of them. The chiefs in most of their utterances can be seen to be agitated because of the fact that they have been cut off in the political dispensation of the country. Recently, some comments from some of the chiefs have stirred up controversies making the citizenry wonder, if the chiefs who are the custodians of the country's customary laws and play an active role in its governance space, are themselves also part of the problem.

This study is an investigation into some comments passed by some chiefs, the problem and controversies, positive or negative that these comments generated and whether it is a fair judgement for one to say that the chiefs are part of the country's political problems. The puzzle posed is that, considering the comments from these selected chiefs in Ghana, is it easier to infer that the chiefs are also part of the problem of Ghana's democratic political space. Is this observation true or not true?

C Monton, The Chieftaincy Institution in Ghana, 2016.

B Chinsinga, 'The Interface between Tradition and Modernity', Civilisations 54, no 1 (2006), 255-274.

H Lefebvre, The Production of Space (Oxford: Blackwell Publishing, 1991). 


\section{COMMENTS BY THE CHIEFS}

On the $15^{\text {th }}$ of September, Togbe Afede XIV, the Agbogbomefia and the Paramount Chief of the Asogli State and President of the National House of Chiefs was addressing a durbar of the people and chiefs of the Asogli State in Ho to climax the 2018 Asogli TeZa Festival was reported to have said, 'if one of the issues to be decided in such a referendum is the boundary of a new region, then it is difficult to see how voting could be limited to the people in an assumed boundary'. ${ }^{12}$ He further went on to say that:

The concentration of the Commission's work on the areas from which petitions came betrayed an early assumption that voting would take place in those areas only. If this thinking holds, then we should prepare ourselves for a flood of requests for, and promises of new regions..$^{13}$

On the same issue, during a meeting of the Volta Regional House of Chiefs he is quoted to have said, 'the ongoing processes towards the creation of new regions poses a threat to peace and unity in the country.' ${ }^{14}$

This comment came against the backdrop of a commission of enquiry that was set up to receive petitions from a cross section of Ghanaians for the creation of new regions in the country and commission had submitted its report to the government and the government has given its blessing for the creation of the new regions. Considering his position and role as the President of the National House of Chiefs, it was to be expected that he would give his fullest support to the agenda of having new regions created or would have sent his sentiments to the commission while it was seating, but not wait after the commission had submitted its report to the government and plans are far advanced for the Electoral Commission to start its work for the regions to be created before raising any misgivings towards the creation of the regions after the necessary constitutional regulations had been met.

The comment by the chief stirred controversy with many saying that his comments were a stab in the back to the good intention of the government to bring development to other places of the country, again, the comments were in bad faith, because he was one particular chief who had on several occasions met the representatives of power and it even came to light that - as was reported by the Minister for Regional Re-organisation and Development - he was shocked for the chief to have passed such comments on the creation of the new regions. This apparent betrayal by the chief on the new creation of regions infuriated sections of the public to question his position as a chief and the head of such a respected traditional institution. Some were also of the view that instead of him being

12 Ghana Business News, 'Maintain constitutional lines in creation of new regions - Togbe Afede', September 17, 2018.

13 Ibid.

14 Kweku Zurek, 'New Regions Dan Botwe Baffled at Togbe Afede’s Baseless Comments' Graphic Online, October 25,2018 . 
a rallying point to preach unity, his utterance is rather creating division and disturbing the peace and cohesion of the country.

This act on the part of the chief prompted the Minister responsible for Regional Re-organisation and Development to issue on 24 October 2018 a press statement highlighting eight key points the ministry had done of which the chief played a yeoman's role:

1. On 17 May 2017, the Ministry held a sensitisation workshop for members of the Volta Regional House of Chiefs in Ho of which Togbe Afede XIV is a member.

2. As required by the constitution [Article 5(2)], His Excellency, the President submitted petitions for the creation of regions to the Council of State (of which Togbe Afede is a member) on 26 June 2017.

3. The Ministry met with members of the Council of State on 25 July 2017 at the conference room of the Ministry of Chieftaincy and Religious Affairs and Togbe Afede was present.

4. The Council of State, which included Togbe Afede on 15 August 2017 advised His Excellency the President of the Republic to proceed with the processes involved in the creation of the new regions.

5. On 6 June 2017, the Ministry met with the revered National House of Chiefs (Togbe Afede is the President of the House) and discussed the procedures and matters related to the creation of the new regions.

6. On 15 January 2018, the Commission met with the Regional House of Chiefs at the Volta Regional House of Chiefs Conference Hall where Togbe Afede was present.

7. On 18 April 2018, the Commission had a consultative meeting with the National House of Chiefs and this was chaired by Togbe Afede XIV.

8. The Minister for Regional Re-organisation and Development honoured two invitations - one in 2017 and another one in 2018 - from Togbe Afede XIV at his office at the World Trade Centre building to discuss issues relating to the creation of the proposed Oti Region.

The statement concluded that:

The eminent men and women who served on this Commission did a great job and deserve commendation, but not insults. The Commission held forty-seven (47) public hearings and forty-one (41) consultative meetings, the attack by Togbe Afede XIV on the work of the commission of inquiry into the creation of the new regions is baseless and should be disregarded.

One can say that the press statement was the straw that broke the camel's back for the citizenry to question the authority of the chief not to be a problem of the democratic space of the nation.

Another comment by a chief that also raised questions was by Nii Ayi Bonte, the chief of the Gbese Traditional Area in the Ga Traditional Council. He made a statement that, should the then incumbent President of Ghana prior to the 2016 general elections, John Dramani 
Mahama lose the elections, he would abdicate his stool as a chief. Owing to the fact that chiefs are held in high esteem and are people who are supposed to be full of integrity and the President he made predictions about lost the elections, it was expected that he abdicated his position. A 2016 report alluded to the fact that 'sections of Ghanaians are demanding Nii Ayi Bonte respects his words by honourably resigning as he promised before scores of people. ${ }^{15}$ Some members of the community expressed their worry in the following ways. 'Gbese Manste! Gbese Mantse! Gbese Mantse! Ofain3 yi shi', to wit, 'Gbese Chief, please abdicate your stool!' Another person also said 'Nii Ayi Bonte, let's see you honour your words, thank you'. 'This is what happens to Chiefs who involve themselves in politics', one other person also added. Adding his voice to the issue, one Ghanaian renowned journalist Abdul Malik Kweku Baako Jnr, also harangued the Chief for his behaviour and had this to say:

Do you see the point we were making that it was unwise for chiefs to put themselves in that partisan way and some of them went to the extreme? Now you went to sit at a durbar, a public space, and pledged to abdicate if one party loses. Why would you make such a pledge? This is total lack of wisdom and wisdom is a key attribute of chiefs or chieftaincy; it's a requirement [...]. When we were saying, they didn't listen. You have somebody who consistently engages in political buffoonery out there insulting our intelligence. Today, the chief has been disgraced, he is hiding in a hole and when he is called, he says: 'I'm not granting interviews.' They should drag him out of the hole and put the microphone right in front of him to talk so we can listen. ${ }^{16}$

One could infer from Mr Baako's submissions and that of others that the chieftaincy institution is sacred and those who occupy it must carry themselves with dignity and do nothing that will denigrate it nor disturb the democratic space by not engaging in politics.

The third comment this article looked at with reference to the topic is that of Nana Osei Tutu II, the Asantehene. Addressing a grand durbar of chiefs and inhabitants of the Abuakwa State in memory and honour of the late Okyehene, the Asantehene suggested the introduction of reforms to the 1992 Constitution to give the chieftaincy institution in the country a more pronounced role in the political space of the nation. ${ }^{17}$ Like most comments by chiefs and controversies that it generates, his comments also generated controversy with many questioning the sort of role he wants the chiefs to play in the democratic space. While others see the call by him as a good one because some chiefs are doing well and should be encouraged, others are of the view that should the chiefs be given any role aside what

Joy Online, 'Pressure mounts on Nii Ayi Bonte to abdicate throne', December 16, 2016.

16 ghanaweb.com, 'It's undignified for Chiefs to owe allegiance to politicians \& presidential candidates - Kweku Baako' May 142020.

17 E Donkor, 'Asantehene Proposes Constitutional Reforms to Give Chiefs Bigger Say in Ghanaian Politics', August 23, 2018. 
the limitations of the constitution imposes on them removed, this would lead to a total destruction of the institution.

These comments, one can say, depending on the time and political temperature in the country, has a way of inviting unwarranted attacks onto the chiefs and one cannot begrudge the citizenry of their attacks on the chiefs because, many have come to understand the injunction in the constitution which bars the chiefs from engaging in active politics or saying something to shape the democratic space of the country, because their positions places them on a higher pedestal and they are also seen as a unifying force and their actions should be one that unites the nation, and not one to divide it.

\subsection{Why they talk}

1. Many of the chiefs have not come to terms with the fact that the country has come under democratic rule and that they are no longer in charge of the day-to-day administration of the country like they did in the past, or the governance space has changed and that their powers too have been reduced.

2. They are still seeing themselves as the first among equals owing to the strong cultural bond that the people hold to the institution as part of the nation's cultural heritage.

3. They see themselves as opinion leaders and mouth pieces of the so-called silent majority.

4. The type of political system practiced in the country (winner takes all) makes them talk as a means of drawing the government of the day's attention to them so they can also attract development to their areas of rule and for their people.

\section{THE ROLE OF THE INSTITUTION}

In the face of these challenges which has warranted many to call into question the role of the chiefs and to a large extent many to conclude that the chiefs are also the problems of the country's democratic and political space the reverse of the role of the institution is good and to a large extent keeping the institution is good for the country's heritage.

\subsection{Peaceful transfer of power}

The procedures for the election and of new chiefs are laid down by traditions and are supposed to be followed in the installation of new chiefs. This is significant because it ensures that there is no struggle among contesting parties for any vacant position of a chief, even though in recent times conflicts have risen in some areas between candidates of various gates. Nevertheless, the institution can be said to be one that provides smooth transfer of power. 


\subsection{Brings unity}

The Chieftaincy institution serves as a unifying force. In other words, the chieftaincy institution brings the people together. The people get involved in the activities of enstooling or enskinning of a chief. They also celebrate and come together and partake in some of the rites of installing chiefs. This ensures that unity prevails in the communities which in the end affects the whole country.

\subsection{Preservation of culture}

The chieftaincy institution helps to preserve the culture of the people. There are procedures in the choice, selection and installation of chiefs under the traditional setting. All these procedures are accompanied by some form of rituals, music and dance. As long as these practices are not compromised but seen as a cardinal ritual of the people, it helps to preserve the culture of the people. Article 270(1) provides for the recognition of the institution of chieftaincy, together with its traditional councils under customary law. According to Article 270 paragraph (2), Parliament shall have no power to enact any law which in any way detracts or derogates from the honour and dignity of the institution of chieftaincy. ${ }^{18}$

\subsection{Promotes stability and development}

The Chieftaincy institution helps to promote peace in the society. It also ensures stability and development in society. As long as there is stability in the society, development is ensured.

\subsection{Social control mechanism}

Chieftaincy is useful as a social control mechanism. The chiefs are traditionally given powers and authority to control their people. They are therefore accorded the respect the office deserves. Those who flout the rules are hauled before the chiefs for trial and guilty ones are punished in order to force the rest of the people to comport themselves.

18 The 1992 Constitution of Ghana, August 15, 1996. 


\section{CONCLUSION}

The paper looked at some comments of Chiefs and the controversies the comments generated making many to come to the conclusion whether the chiefs can be part of the problems of Ghana's democracy and political space. Indeed, some comments by them had generated debates to a large extent. However, some of the comments were not only vague comments, ${ }^{19}$ some of them prompted the government machinery to explain things better to the masses and also the chiefs received a flak for their comments and actions. Nevertheless, the chiefs as acknowledged by Ugandan President Yoweri Museveni, 'while governments are busy focusing on roads and other such infrastructural developments, cultural leaders (Chiefs) play the important role of preserving customs and the identities of the people..$^{20}$ In the words of Ubink, the function of dispute settlement, ensuring community participation in development, ensuring peace in the community and looking after the physical development of the town has been one unique area the chiefs have played the yeoman's role and the only way they could be heard and lobby governments is when they talk. ${ }^{21}$

Bonna, O, 'Otumfuor Nana Osei Tutu II, A Role Model For African chiefs (I)', 2006.

Unesdoc.Unesco.org, Culture Urban Future: Global Report on Culture for Sustainable Urban Development.

J M Ubink, In the Land of the Chiefs. Customary Law, Land Conflicts and the Role of the State in Peri-Urban Ghana (Leiden: Leiden University Press, 2008). 


\section{REFERENCES}

1. Adjei, G K, 'Traditional Akan Royal Chieftaincy Institution: Evolving Ceremonial Protocol in Chieftaincy at Duayaw-Nkwanta in Ghana'. Legon Journal of the Humanities 26 (2015), 1-18. DOI: 10.4314/ljh.v26i1.1

2. Amoatia Ofori Payin, O, Chiefs and Traditional Authorities and their Role in the Democratic Order and Governance. Paper Presented at the ${ }^{\text {th }}$ IEA Ghana Constitutional Review Series, 2010.

3. It's undignified for Chiefs to owe allegiance to politicians \& presidential candidates - Kweku Baako. 2020. www.ghanaweb.com/GhanaHomePage/NewsArchive/It-s-undignified-forChiefs-to-owe-allegiance-to-politicians-presidential-candidates-Kweku-Baako-951997 (accessed 10 December 2020).

4. Bonna, O, 'Otumfuor Nana Osei Tutu II, A Role Model For African chiefs (I)', 2006. www.ghanaweb.com/GhanaHomePage/NewsArchive/The-Role-Of-ChieftaincyIn-Ghana-103219 (accessed 10 December 2020).

5. Blom, A, 'Ambiguous Political Space: Chiefs, Land and the Poor in Rural Mozambique', in In the Name of the Poor: Contesting Political Space for Poverty Reduction, ed. by Neil Webster and Lars Eng-Perdersen. New York - London: Zed Books, 2002.

6. Chinsinga, B, 'The Interface between Tradition and Modernity'. Civilisations 54, no 1 (2006), 255-274. DOI: 10.4000/civilisations.498

7. Donkor, E, 'Asantehene Proposes Constitutional Reforms to Give Chiefs Bigger Say in Ghanaian Politics', August 23, 2018. https://emmanueldonkorghana.blogspot. com/2018/08/asantehene-proposes-constitutional.html (accessed 10 December 2020).

8. GhanaBusinessNews, 'Maintain constitutionallinesincreation ofnewregions-TogbeAfede', September 17, 2018. www.ghanabusinessnews.com/2018/09/17/maintain-constitutionallines-in-creation-of-new-regions-togbe-afede/ (accessed 10 December 2020).

9. Joy Online, 'Pressure mounts on Nii Ayi Bonte to abdicate throne', December 16, 2016. www.myjoyonline.com/news/pressure-mounts-on-nii-ayi-bonte-to-abdicatethrone (accessed 10 December 2020).

10. Graphic.com.gh, 'New Regions' Dan Botwe Baffled at Togbe Afede's Baseless Comments' October 25, 2018. www.graphic.com.gh/news/general-news/new-regions-dan-botwebaffled-by-togbe-afede-s-baseless-comments.html (accessed 15 December 2020)

11. Knierzinger, J, 'Chieftaincy and Development in Ghana: From Political Intermediaries to Neotraditional Development Brokers'. AP IFEAS 124 (2011).

12. Lefebvre, H, The Production of Space. Oxford, Blackwell Publishing, 1991.

13. Lule, G, The Role of Traditional Leaders in the $21^{\text {st }}$ Century. Paper presented at the Sheraton Hotel in Kampala on 28 July 1995.

14. Monton, C, The Chieftaincy Institution in Ghana, 2016. www.virtualkollage.com/2016/07/ the-chieftaincy-institution-in-ghana.html (accessed 08 November 2018).

15. Obarrio, J, Legal Pluralism and Peace Process: The Ambiguous Reemergence of Customary Law in Mozambique. Program on Global Security and Cooperation Research Project, Switzerland, 2002. 
16. Owusu, M, 'Domesticating Democracy: Culture, Civil Society and Constitutionalism in Africa'. Comparative Studies in Society and History 39, no 1 (1997), 120-152.

17. Ribot, J, African Decentralization: Local Actors, Powers and Accountability. UNRISD Programme on Democracy, Governance and Human Rights, Paper Number 8, Stockholm, 2002.

18. The 1992 Constitution of Ghana, August 15, 1996. http://extwprlegs1.fao.org/docs/ pdf/gha129754.pdf (accessed 10 December 2020).

19. Ubink, J M, In the Land of the Chiefs. Customary Law, Land Conflicts and the Role of the State in Peri-Urban Ghana. Leiden. Leiden University Press, 2008. DOI: $10.5117 / 9789087280413$

20. Culture Urban Future: Global Report on Culture for Sustainable Urban Development. https://unesdoc.unesco.org/search/N-EXPLORE-ebb272b0-8c0d-4930-ad4caelbb4e66242 (accessed 15 December 2020)

Emmanuel Abeku Essel is currently a final year PhD student at the University of Public Service. He earned his Bachelor's and Master's degrees at the University of Cape Coast, Ghana, where he also worked as Administrator/Alumni Relations Officer and filled the position of Chief Administrative Assistant from 2003 to 2020. His experience also includes two years at the Department of Religious Studies, University of Cape Coast as a Teaching and Research Assistant and also ten years at Radio Gold, Radio Central and ATL Fm as a Host and a Reporter. His main research interest includes Governance and African Traditional Governance. Indigenous Knowledge Systems (IKS) on taboos and Traditional African Ethics. Currently, he is the author of three peer-reviewed journal articles and eight international conferences. He also has two papers under-review and three conference papers yet to be published. 